\title{
Thinking Contexts in Southern Europe Education Policy Analysis: Towards a Literature Review
}

\author{
Pensar en los contextos en el análisis de las políticas educativas \\ en la Europa del Sur: hacia una revisión bibliográfica
}

\section{Xavier Pons ${ }^{1}$}

\begin{abstract}
This article presents the very first findings of a scoping literature review on how scholars who work on French, Italian and Portuguese education policies consider and possibly conceptualise policy contexts in their analysis. Going through 175 articles published either in English or in French, it shows that the authors in the publications studied tend to contextualise little the analysis of education policies and that when they do so, there are no specific contextualisation operations for authors working on Southern European countries. Nevertheless, the presence of different analytical sensitivities from one country to another, as well as the still numerous limitations of our method, which is still in progress, suggest that the construction of a specific problematisation space remains possible, particularly around the logics of vernacularisation of global policy statements and requirements.
\end{abstract}

\section{Keywords}

Education policy, context, Southern Europe, literature review, sociology, vernacularisation.

\section{Resumen}

Este artículo presenta las primeras conclusiones de una revisión bibliográfica sobre la manera en que los investigadores que trabajan sobre las políticas educativas francesas, italianas y portuguesas consideran y posiblemente conceptualizan los contextos políticos en sus análisis. Recorriendo 175 artículos publicados en inglés o en francés, muestra que los autores de las publicaciones estudiadas tienden a contextualizar poco el análisis de las políticas educativas y que, cuando lo hacen, no hay operaciones de contextualización específicas para los autores que trabajan sobre los países del sur de Europa. No obstante, la presencia de sensibilidades analíticas diferentes de un país a otro, así como las limitaciones aún numerosas de nuestro método, que todavía está en curso, sugieren que la construcción de un espacio de problematización específico sigue siendo posible, en particular en torno a las lógicas de vernacularización de las políticas públicas globales.

\section{Palabras clave}

Política educativa, contexto, Europa del Sur, revisión bibliográfica, sociología, vernacularización.

\section{Cómo citar/Citation}

Pons, Xavier (2022). Thinking Contexts in Southern Europe Education Policy Analysis: Towards a Literature Review. Revista de Sociología de la Educacion-RASE, 15 (1), 25-44. http://dx.doi.org/10.7203/RASE.15.1.22161. 


\section{Introduction}

This article examines the importance given by researchers publishing on education policies developed in Southern European countries to the contexts in which these policies are implemented. For JeanClaude Passeron, sociology, as a 'science of the course of the historical world' ${ }^{2}$, can be understood, like history, as a 'science of context' (Passeron, 2006: 20) ${ }^{3}$. For the author, this context designates a 'subset of the historical world' which the sociologist fundamentally needs to establish his descriptions, to base his/her empirical assertions and to control his/her theoretical interpretations. What then is the situation in the field of sociological analysis of educational policies? What contextualisation operations do researchers in this field engage in?

Addressing such questions has at least two objectives. The first one is to fuel general sociological knowledge on the importance of contextualising objects of research studied in a sociological way. This question seems particularly interesting to ask in the field of research on education policies since many works now insist on the globalisation of their conception. This is said to take place through various vectors of dissemination: the role of international organisations (Charlier, 2003, Jakobi, 2009, Grek, 2009 and many others), but also of NGOs (Barlet \& Jarousse, 2011) and more recently of a new generation of philanthropic foundations (Ball, 2008); the influence of international comparisons on the formulation of educational policies through, for example, the so-called 'Pisa shock' (Pons, 2017); the central role of new networks of globalised experts (Normand, 2010) in the promotion of new measurement tools (Ozga et al., 2011); the worldwide dissemination of transnational doctrines such as New Public Management aimed at improving the efficiency of public administrations, the quality of education and regulating by results (Maroy, 2013, Gunter et al., 2016, Normand et al., 2019), not forgetting the phenomena of regionalisation of educational policy areas which are all adaptations to globalisation, as in the case of the Lisbon Strategy and the construction of a European educational policy area (Lawn \& Grek, 2012). The effects of this diffusion on modes of governance and policy-making highlighted in the literature are extremely numerous: diffusion of a 'soft' governance of education (Lawn, 2006), redefinition of education as of lifelong learning (Nóvoa \& Lawn, 2002, Jakobi, 2012), 'comparative turn' (Martens, 2007), benchmarking and promotion of 'new educational policies' (Mons, 2007), definition of new commensurable spaces of regulation and redefinition of the relevant political scales (Lingard \& Rawolle, 2011, Lingard \& Sellar, 2014), the development of a 'government by numbers' (Grek, 2009) and a new 'globalised panopticon' (Lingard, Martino \& Rezai-Rashti, 2013), but also the dematerialisation of policy processes and the acceleration of data flows and the transfer of ideas well beyond the borders of state sovereignty, thus defining new 'policyscapes' (Carney, 2012).

Therefore we can legitimately wonder if we are not witnessing the construction of a new, globalised 'common sense of reform' (Topalov, 1999), which would relegate to the background the consideration of domestic contexts for the design and implementation of education policies, and which would be based on the promotion of decontextualised reforms and measures, which can travel rapidly in the name of their so-called effectiveness, according to a movement that some people have now described as 'fast policy' (Peck \& Theodore, 2010; Hardy, Heikkinen \& Olin, 2020).

2 This is our direct translation from the text in French.

3 In the 1991 edition, the sociologist speaks instead of «contextual disciplines». 
The second objective refers to the reflections on theories of the South (Connell, 2007) or 'epistemologies of the South' (Santos, 2014) and their consideration at the scale of the 'contexts' of Southern Europe, as the Revista de la Asociación de Sociología de la Educación (RASE) already questioned in a recent issue (Santagati et al., 2019). To these we could probably add many reflections in anthropology and international relations theory on what Jean-Pierre Olivier De Sardan (2021) calls 'the revenge of contexts' in his analysis on cash transfers. Are there educational policy contexts specific to Southern European countries and how do the authors address them? More precisely, are there specific ways of contextualising education policies for the authors working on these countries that would highlight a 'Southern way' of conducting policy analysis?

In the field of European research on education policies, we are not starting from nowhere on these issues. From the very beginning of the construction of a 'policy sociology' in education, Stephen Ball insists on the importance, for the analysis of the policy cycle, of producing a critical and contextualised analysis of education policies (Lingard \& Sellar, 2013). He thus distinguishes between different contexts that the researcher must consider studying the trajectory of education policies, the way in which they circulate in different spaces and levels and how they are adapted, translated and 'recontextualised' by the actors. He first distinguishes between the context of influence (where interest groups struggle over the construction of policy discourses), the context of text production (where texts represent policies, in relation to other texts) and the context of practice (where policy is subject to interpretation and recreation) (Bowe, Ball \& Gold, 1992), and in a second contribution, the context of outcomes (where the impact of policies on existing social inequalities is seen) and the context of political strategy (where political activities are identified to tackle such inequalities) (Ball, 1994).

Nevertheless, our approach does not consist in starting from a strong theoretical definition of the notion of policy context that would inevitably conveys a specific position in a field of research that we want to study in its diversity. As Bernard Lahire points out, the operation of contextualisation touches on the very identity of social scientists since it implies choices that are specific to them and allow them to position themselves in a field of knowledge. These include choices of vocabulary, method and the 'scale of context' of the analysis (Lahire, 1996: 406). Our approach is more empirical: it studies how researchers working on French, Italian and Portuguese education policies take up the imperative of contextualisation through a review of the Anglophone and Francophone literature on these three countries.

The analysis shows that the authors of the publications studied tend to contextualise little the analysis of education policies and that when they do so, we do not observe any specific contextualisation operations for authors working on Southern European countries. Nevertheless, the presence of different analytical sensitivities from one country to another, as well as the limitations of our method, suggest that the construction of a specific problematisation space remains possible, particularly around the logics of vernacularisation of global policy statements and requirements.

Before presenting these points, let us finally clarify the spirit of our approach. Our aim is not of course to carry out any kind of «'science police' [which] would decide between the good and bad uses» of contextualisation (Feuerhahn, 2017: 10). Following Bernard Lahire (1996), the idea is to understand the variety of contextualisation choices made and to highlight the knowledge effects produced by them. In this sense, this literature review is an invitation to collaborate to colleagues who wish to deepen this reflection. 


\section{Methodology}

This presentation is based on a literature review carried out as part of a report which was submitted in September 2021 to the Centre national d'évaluation du système scolaire (Cnesco) ${ }^{4}$ in France. We were commissioned to study the 'context and meaning of the implementation' of education policies in France and in other countries. The initial idea was that an educational policy emerges in a social and semantic universe and an already structured school field and that it is therefore part of a history and a context that will influence the making of educational policies and the meaning that the actors will give them.

This review can be defined as a scoping review. Focusing on theoretical aspects, its objective is to «map rapidly the key concepts underpinning a research area and the main sources and types of evidence available» (Mays et al., 2001: 194) to «examine the extent, range and nature of research activity» and to «identify [possible] research gaps in the existing literature» (Arksey \& O’Malley, 2005: 21). This review is based on the intensive analysis of a corpus of 175 research articles, in both English ( $\mathrm{n}=98$ ) and French ( $\mathrm{n}=77)$.

Several stages of research were necessary to constitute this corpus. First, we queried two types of online databases known for the richness of their document collection - commonly used portals giving access to numerous journals (Eric and GoogleScholar for the English-speaking works, Cairn, Erudit, Openeditions and Persée for the French-speaking part) and the online search engines of the publishers of large international journals particularly relevant to our object, such as Sage (European Educational Research Journal, EERJ), JSTOR (Comparative Education Review, CER) and Taylor \& Francis (Comparative Education, CE; Compare; Discourse; Journal of Education Policy, JEP and Globalisation, Societies and Education, GSE).

In each of these databases, we carried out a keyword search, primarily in the abstract field with the use of truncation as systematically as possible. The series of keywords were adapted to the possibilities given by each search engine (see table I). For the part targeting English-language journals, we deliberately opted for a broad search that only mentioned the name of the country in all fields. The idea was to complete the Eric and GoogleScholar databases by trying to reach articles that would have escaped the previous search phase.

Then we went through or read the 8,021 abstracts of articles obtained in this way, and in the end, we selected 175 of them (see Table II). In hindsight, we realise that the consultation of so many records $(8,021)$ by a single researcher may seem highly unrealistic. This was possible for three main reasons. The first is that these global numbers often aggregate identical publications: in fact, each time we varied a keyword (for instance «reform» rather than «policy»), there were many duplicates which we did not take care to distinguish in the calculation of the global number of contributions, to save time. The second reason is that the publishers' search engines, despite our targeting of the three countries studied, identified many articles that mentioned them in their content, without the analysis focusing specifically on them. It was therefore very easy, based on titles and abstracts, to quickly exclude articles on other countries or geographical areas. Thirdly, many of the entries referred to bibliographies proposed by the journals, to book reviews, sometimes to letters from readers or to editorials, in short to

4 http://www.cnesco.fr/fr/accueil/ 
sections that we did not include in the scope of the analysis. In addition to these three reasons, there were other more conventional reasons for non-selection: lack of general relevance (very old historical periods, articles that were too short as in the case of quick introductions to special issues, macro statistical comparative articles that did not go into the details of national contexts) and the focus of articles on fields other than school education (adult education, nursing, etc.).

Table I. Bibliography database (1): sources, fields, and keywords

\begin{tabular}{|c|c|c|}
\hline BASES & FIELDS & KEYWORDS \\
\hline Cairn & Journals, abstracts & 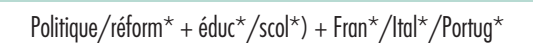 \\
\hline OpenEdition & OpenEdition Journals Abstracts & Politique/réforme + éducation/scolaire +France/ltalie/Portugal \\
\hline Erudit & Titles, abstracts, keywords & 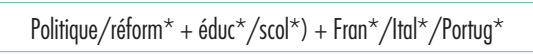 \\
\hline GoogleScholar & Titles only, without the quotes & Politique/réforme + éducation/scolaire +France/ltalie/Portugal \\
\hline Eric & All fields, journal articles only, thematic «educational policy» & France/Italy/Portugal + policy \\
\hline Sage & EERJ, all fields & France/Italy/Portugal \\
\hline JSTOR & CER, all fields & France/Italy/Portugal and policy \\
\hline Taylor \& Francis & Compare All fields & France/Italy/Portugal \\
\hline Taylor \& Francis & Discourse All fields & France/Italy/Portugal \\
\hline Taylor \& Francis & Compare All fields & France/Italy/Portugal \\
\hline Taylor \& Francis & JEP All fields & France/Italy/Portugal \\
\hline Taylor \& Francis & GSE All fields & France/Italy/Portugal \\
\hline
\end{tabular}

Source: Author. Last query: 30 April 2021.

Table II. Bibliography database (2): number of items per country

\begin{tabular}{lcccccc}
\hline SOURCES & \multicolumn{2}{c}{ FRANCE } & \multicolumn{2}{c}{ ITALY } & \multicolumn{2}{c}{ PORTUGAL } \\
\hline Cairn & Records & Articles selected & Records & Articles selected & Records & Articles selected \\
\hline OpenEdition & 742 & 49 & 69 & 8 & 18 & 3 \\
\hline Erudit & 381 & 5 & 35 & 1 & 35 & 5 \\
\hline GoogleScholar & 378 & 4 & 11 & 2 & 5 & 0 \\
\hline Eric & 53 & 5 & 319 & 19 & 126 & 0 \\
\hline EERJ & 243 & 19 & 233 & 2 & 173 & 21 \\
\hline CER & 350 & 4 & 367 & 3 & 250 & 4 \\
\hline CE & 743 & 2 & 296 & 1 & 181 & 0 \\
\hline Discourse & 818 & 4 & 93 & 1 & 43 & 0 \\
\hline Compare & 265 & 0 & 189 & 0 & 170 & 0 \\
\hline JEP & 553 & 1 & 91 & 0 & 63 & 0 \\
\hline GSE & 343 & 7 & 73 & 39 & 71 & 1 \\
\hline Total & 235 & 100 & 1779 & 1136 & 2 \\
\hline
\end{tabular}

Source: Author. Last query: 30 April 2021.

We then read and coded these 175 articles in three dimensions for the sake of the report that we had to produce: contexts, policy fabrication and rationalities of the policy process. In this article, we deliberately focus on the first dimension related to contexts, in accordance with the reflection that guides us in the introduction. This choice has its limits, however, because considering the other two dimensions (how the authors analyse policy making and what rationalities of policy processes they highlight) also helps to 
understand how they take contexts into account, and even how they conceptualise them. Nevertheless, a balanced analysis of the three dimensions did not seem realistic in the format of such an article. For each dimension, we took care to distinguish several sub-dimensions and research questions (see table III). Table III summarises these for the context dimension.

The analysis of this corpus is still in progress. The following remarks should therefore be understood as a series of intermediate results, which still need to be confirmed by further analysis.

\section{Table III. Bibliography database (3): coding, the example of the context dimension}

\begin{tabular}{|c|c|}
\hline \multicolumn{2}{|c|}{ DIMENSION 1. CONTEXTS } \\
\hline Sub-dimensions & Main questions \\
\hline Empirical aspects & $\begin{array}{l}\text { What is the importance of exo-nationalisation phenomena? What is the relevance of the denationali- } \\
\text { sation hypothesis? How relevant is the idea of decontextualised policies? What is the importance of } \\
\text { traditional modes of regulation and policy communities specific to each system? How is the field of } \\
\text { school policy structured? How is this context reflected in the policy process: by a model of political } \\
\text { education? Values? Historical or political trajectories? A linguistic particularity? }\end{array}$ \\
\hline Methodological aspects & $\begin{array}{l}\text { How do the authors think these contexts? With what methods? Are they demonstrated, asserted, taken } \\
\text { for granted? How do the authors delimit the scope of the analysis when 'contextualising'? Where do } \\
\text { they stop? }\end{array}$ \\
\hline Theoretical aspects & $\begin{array}{l}\text { What theoretical frameworks are used to understand the role of contexts in the policy process? Which } \\
\text { concepts or notions are more specifically used to think about contexts themselves? What vision(s) of } \\
\text { contexts emerge? Complementary variables of the analysis reintroduced by the researcher? Social (and } \\
\text { therefore also political, cultural, etc.) reference spaces in which public policies are inevitably embedded } \\
\text { and which must be conceptualised (fields, configurations, policyscape, etc.)? Empirical variations of the } \\
\text { same phenomenon? Statements that are complementary to the public policy statements themselves, } \\
\text { that are implicit or isolated, more or less intentionally, but that are necessary for the understanding of } \\
\text { the public policy statement put forward by the government? }\end{array}$ \\
\hline
\end{tabular}

\section{No Southern European Way of Contextualising Education Policies}

An initial analysis of this corpus shows that it is still difficult to establish the existence of modes of contextualisation of the education policies studied which would be specific to the authors working on the three countries studied, for several reasons.

\subsection{Contextualisation is not always a common concern}

Firstly, in a non-negligible proportion of the articles in our corpus, the authors do not simply engage in a minimal contextualisation of the education policies they study. This is the case for 10 articles out of 39 for Italy (about 25.6\%), 14 articles out of 36 for Portugal (about 38.9\%) and 72 articles out of 100 for France. The articles grouped in this first category have several different profiles. A significant proportion of them consist of case studies or monographs on current education policy, which remain resolutely descriptive, and whose primary purpose is to offer an analysis of the current situation to a largely foreign readership. This is the case of several articles on Italy or Portugal published in French, for example in the Revue internationale d'éducation de Sèvres (Bertiglia \& Panaro, 1996; De Renzo, 1997; Ferreira, 2007), or of articles on the three countries studied published in sections dedicated to this type of analysis, as may have existed in the past in certain international journals such as the Comparative education review (Borghi \& Scarangello, 1960). Another profile is that of articles that are situated from the outset in a macroscopic comparative approach which, if it integrates the countries studied, favours either the presentation of axes of analysis that cut across them (Michel, 2017; Pons, 2012a), or theoretical modelling of which these countries constitute specific types (Maroy, 2009). A final profile 
refers to articles in which the contextualisation phase of the policy studied is evacuated in a self-evident manner, as if the authors were assuming that this overall context was known. This is the case of a large number of articles on France written in French, almost always by French authors, and where it can be assumed that the authors think they share with their readers an implicit common knowledge that justifies not going back over elements of context. However, this explanation is not fully convincing either, since this case is also found in English-language articles on the three countries (Cardoso, 2008; Mesquita, 2012; Power \& Frandji, 2010; Romito, 2019).

\subsection{Little reflection on education policy 'cases'}

Moreover, when the authors of our corpus engage in a form of contextualisation, in many articles this contextualisation consists in making the country studied an example of general trends, a field of investigation among others that can illustrate these trends. Rarely do these articles analyse the country studied as a 'case' of education policy, in the sense given to this term by Jean-Claude Passeron and Jacques Revel (2005).

For the latter, a 'case' is a 'singularity accessible to observation' (Passeron \& Revel, 2005: 9). This singularity surprises: the case always produces a surprise effect. It implies interrupting the usual perception of a research object, it poses problems of its own and in this sense, for them, the case breaks with the usual generalisations of the sociologist. Therefore, for these authors, a case cannot be a simple example. It contains its own truth which can only be seen by taking the context into account. Consequently, for our purposes, it is interesting to determine when the authors make French, Italian or Portuguese education policies into 'cases' because it is perhaps at this stage of the analysis that they engage in forms of contextualisation that are specific to them.

However, among the articles that propose a minimal contextualisation of the policies studied, many of them focus on a few general historical or morphological aspects of the education systems, or sometimes of the political systems studied, and then make the country studied a simple illustration of general trends. This tendency can be found in all three countries studied. Italy is often described in the articles in our corpus as a country with a high degree of ministerial instability, placed under the vigilant surveillance of the European Union and international organisations in terms of budgetary policy, and within which the regulatory power of the central state remains limited. These elements would explain the globalisation of quality measurement in this country (Engel \& Rutkowski, 2014). Similarly, the French model, apparently ‘historically known for its more introverted approach to education', would be challenged by a secondary education policy aligned with the Finnish model promoted internationally through Pisa (Dobbins \& Martens, 2012). This aspect seems even more visible in the articles in our sample devoted to Portugal. Although they recall the particular historical and political context of this country (the experience of the dictatorship, the major role of the school in the democratisation phase and the political orientations taken by successive governments), these articles often conclude that the education policy of this country is aligned with exo-national (international, European, transnational) norms or trends such as the neo-liberal privatisation of education (Adrião \& Silva, 2020; Estrela, 2019), its commodification (García Redondo, 2016), the promotion of an inclusive school in line with international standards (Alves, 2019) or the globalisation of Portuguese policy through its Europeanisation (Antunes, 2016). 


\subsection{No specific methodology to capture contexts}

It should also be noted that, from a methodological point of view, the methods used from one article to the next are very regular. When these methods are explained, which is not always the case in summary articles (on a country or on a comparative survey published elsewhere), they essentially consist of interviews with actors in the policy process, analyses of a corpus of documents ("policy documents', official texts, press articles) and archives, to which are sometimes added methods characteristic of network ethnography. This regularity does not allow us, at least with the possibilities offered by the canons of international article writing, to carry out an in-depth methodological reflection on the delimitation and operationalisation of a possible contextualisation. This variable or sub-dimension of our analysis does not prove to be discriminating on this point.

\subsection{Two main (globalized) sources of theoretical inspiration}

Lastly, on a theoretical level this time, our corpus highlights a relatively important diversity of theoretical frameworks mobilised to conceptually define the relevant education policy contexts. For instance, some authors use the following concepts to think these contexts, without always defining them precisely: 'policy ecology' (Alves, 2020), 'recontextualisation' (Antunes, 2004; Carvalho \& Costa, 2015; Mathou, 2018), 'configuration’ (Landri, 2015; Müller \& Hernández, 2010), 'environment ontology’ (Santos, 2021), 'power structure' (Coombs, 1978) or 'policy field’ (Clément, 2021).

Despite this diversity, two sources of inspiration clearly stand out. The first one, unsurprising in view of the structuring of an international, largely European, field of research on 'policy sociology', refers to the work of Stephen Ball, which is very often cited. However, it is less the detailed analysis of policy contexts that is mobilised - we found it explicitly developed in only one article in our corpus (Hyatt \& Meraud, 2015) - than the notions of bricolage/assemblage and trajectory that seem to inspire the greatest number of authors (Adrião \& Silva, 2020; Álvares, 2018; Barzanò \& Grimaldi, 2013; Carvalho et al., 2020; Estrela, 2019; Maroy et al., 2017; Serpieri et al., 2015; Teodoro \& Estrela, 2010). This notion of trajectory is sometimes coupled in some articles with the analytical frameworks of historical neo-institutionalism (notion of path dependency, Kathleen Thelen's work on gradual change), which constitute the second main source of theoretical inspiration in the three countries studied (Álvares, 2018; Berthet, 2019; Garcia, 2015; Grimaldi, 2013).

This last result is consistent with another literature review that we were able to conduct recently with Christian Maroy on the different conceptualisations of the globalisation of education policies proposed by researchers who adopt a neoinstitutionalist theoretical framework. This review highlights three major international research issues which structure research in this field and which tend to be sedimented rather than sequential. The second is precisely to use the tools of sociological and historical neoinstitutionalism to think about the contextualised mediations of educational globalisation (Maroy \& Pons, forthcoming).

The important point to emphasise at this stage of our analysis is that these two sources of inspiration refer to highly internationalised theoretical frameworks. This is a logical and relatively obvious point given the increasing internationalisation of educational policy research. But it is also one more conclusion pointing to a lack of contextualisation specific to authors working on education policies implemented in Southern Europe. 


\section{The need for a more detailed examination}

The remarks made in the previous section converge to highlight 1) a rather weak consideration of sociological (and historical) debates on the imperative of contextualisation in the work on education policies implemented in France, Italy, and Portugal (first knowledge objective mentioned in the introduction), and 2) the a priori absence of modes of contextualisation of these policies that would be specific to authors studying these three countries (second knowledge objective). In the light of these first results, we could wonder, to continue with the considerations developed in the introduction, whether this global absence of contextualisation does not convey, at least indirectly, the vision of globalised education policies that the promoters of the latter want to give, namely generic policies that can be effectively implemented in a wide variety of contexts, and therefore whether this weak contextualisation does not contribute to legitimising the image of a new globalised common sense of reform, although this may not be the authors' intention. Nevertheless, two sets of considerations invite us to a more in-depth examination that could lead to a more nuanced response.

\subsection{Towards country-based contextualisations?}

A comparison of the articles by country within our overall corpus highlights some 'national' specificities. The articles on Portugal, for example, very often focus on the question of transformations in the modes of regulation and evaluation of the Portuguese school system or of certain of its components. These articles draw heavily on international literature on the recomposition of governance in education (particularly in comparative education) rather than on works or theories forged in Portuguese 5 . Many of them insist at some point in the analysis on the role of the European Union in shifting and then stabilising an educational policy trajectory and, as we have seen above, several of them ultimately conclude that there has been a form of European or international normalisation of Portuguese policy. The public policy contexts are thus most often ignored, or simply recalled as a reminder of the country's great political history and democratic normalisation... unless the issue of Europeanisation is an integral part of the Portuguese context itself. This is precisely the perspective adopted by António Teodoro and Elsa Estrela in their analysis of the trajectory of curricular policy in this country between 1995 and 2007. Indeed, these authors show how this policy is a form of bricolage between several imperatives, including the process of Europeanisation itself seen as a regional reconfiguration that implies a national reconfiguration of the education policy studied (Teodoro \& Estrela, 2010).

As for the articles on Italy, we were struck by the importance of Emiliano Grimaldi's work for our subject, which alone accounts for more than a quarter of the publications in our corpus on this country (10 out of 39). These works, as well as those taken up by other authors, have first allowed the progressive stabilisation of a specific contextualisation of the Italian case. This contextualisation emphasises, in addition to the elements of classical political history, the characteristics of the Welfare State in this country, its strong bureaucratisation (stronger than in France, it is sometimes written in certain articles), the weight of the hierarchy, the very strong cyclical instability of education policies (stop-and-go dynamics) and the political resistance and the feeling of inefficiency of the public school that these previous characteristics produce (Grimaldi, 2012b; Grimaldi \& Serpieri, 2013a, 2013c). To this standard contextualisation, but also consistent with it, are added, according to the needs of the

5 This does not prevent us from finding in our corpus several authors who contribute strongly to structuring a field of questioning on Portuguese education policies, such as F. Antunes, L-M. Carvalho or A. Novoá. 
demonstration, the idea that the New Public Management and the evaluation tools were introduced late and that the successive economic crises (in particular that of 2008) have further weakened the capacity for action of the Italian governors by reducing their budgetary margins of manoeuvre and increasing the surveillance carried out by international organisations and the European Union (Grimaldi \& Landri, 2019; Grimaldi \& Serpieri, 2013b; Hall et al., 2015). Moreover, Emiliano Grimaldi remains one of the authors in our corpus who has taken the analysis of context effects on Italian politics the furthest. We can even observe a certain evolution in the author's work overtime, but also and above all according to the issues selected and the insights provided, sometimes from the same data and the same initial surveys. While he has always tried to keep together the phenomena of globalisation and the consideration of contexts, he concludes rather in favour of a neoliberalization of Italian policy in his article on inclusion policy ${ }^{6}$, whereas the two articles in our corpus written with Giovanna Barzanò on the evaluation of teachers' merit conclude, one, that Italian evaluation policy has been vernacularized (Barzanò \& Grimaldi, 2013) and, the other, that it has undergone a 'merit turn' (Grimaldi \& Barzanò, 2014). Far from seeing these developments as inconsistencies, we regard them as similar attempts to consider the effects of contextualisation in the analysis of educational policies. This fundamental questioning leads the author on several occasions to seek out what makes the Italian policy trajectory unique'. It even leads him to propose in an 'essay' 'a critically informed toolbox of diverse concepts for education policy analysis' that considers the contexts of practice (Grimaldi, 2012a).

Lastly, concerning the publications on France, it would seem that the authors rely more heavily on the sociology of public action, which can be understood as the French variant of the international current of policy analysis (Halpern et al., 2018), than their Italian and Portuguese counterparts (Barrault-Stella, 2012, 2016; Bongrand, 2012; Buisson-Fenet, 2004a, 2004b; Buisson-Fenet \& Pons, 2012; Dupuy, 2012; Dupuy \& Pollard, 2013; Pons, 2012b; Robert, 2007). It would also seem that they rely more than their Italian and Portuguese colleagues on specifically French bodies of reference that refer either to specific traditions of analysis, such as the sociology of tests («épreuves» in French) inspired by the work of Luc Boltanski and Laurent Thévenot (Derouet, 2006, 2008; Dutercq, 2009), or to thematic specialisations, as evidenced by the numerous works on priority education policies (Heurdier, 2014, 2016; Rochex, 2008, 2016, 2018). It seems that the combination of these two elements results in a logic of binary contextualisation which leads authors on France either not to contextualise education policies at all on the grounds that their analysis stems from a corpus of references taken to be self-evident and shared, or to strongly contextualise the case, particularly in articles published in English, even if it means explicitly positioning it as a major 'case' for analysis.

\subsection{Learning from methodological limits}

The second set of reasons that invite a more nuanced statement is the limitations of the literature review that we propose in this article. We distinguish three in particular whose consideration could considerably improve our understanding of the contextualisation processes at work.

\footnotetext{
«The study offers evidences to support the thesis that, notwithstanding the specificities of local re-contextualisations, the widespread influence of a heterogeneous set of neoliberal discourses has the power to weaken and divert education policies intended to pursue social justice and inclusion» (Grimaldi, 2012).

7 «Our analysis, however, illustrates also the distinctiveness of the Italian trajectory. [...] This is quite evident, for instance, in the reclaiming of the 1970s tradition of democratic experimentalism in a way that is currently politically legitimate (economy — and system-oriented) and practically usable. We suggest that there is a particular Italian inflection 'of a typical EU balance' between economic rationalism and social justice. [...] This is then a permanent struggle where intertextuality is at work. The recent formulation of the 2018 global and integrated national strategy to tackle ESL in Italy could be seen as the policy site where all these tensions and this troubled process of re-culturing shows itself in all its paradoxical traits» (Grimaldi \& Landri, 2019).
} 
Firstly, the bibliographic databases consulted here should be supplemented in several ways, for example by considering other English-language databases that list purely sociological works (not only works on education), or by addressing other types of publications than articles. In France, for example, major contributions to the analysis of education policies are still to be found in the form of books.

Secondly, the analysis of the three proposed countries should be complemented by a review of the literature in Italian and Portuguese, based on bibliographic sources or portals relevant to the research communities concerned. Indeed, a comparison of the publications in our corpus on France proposed in English and in French highlights important differences. While the French-language articles on France reflect a diversity of disciplines with a strong representation of historians and researchers in educational sciences («sciences de l'éducation» in French), the English-language articles are produced by a very small number of authors with a more assertive sociological profile, which also implies a focus on the preferred themes of these few authors. For example, together, Christian Maroy, Agnès van Zanten and ourselves (co-)wrote 13 of the 40 English-language articles on France in our sample. It is therefore possible that our remarks on the works produced on Italian and Portuguese education policies suffer from a very important source bias.

Thirdly, it seems central that we also contextualise our own analysis of these publications much more by considering the ways in which research on education policies is structured in the three countries studied. For example in France, a case we know much better than the two others, it is difficult to understand the presence of historians, for example, or the ability of certain administrative elites to publish in international journals on education policies (see for instance Gauthier \& Le Gouvello, 2010 or Michel, 2017), without taking into account the academic traditions present and their evolution on the one hand (Buisson-Fenet, 2007), and on the other the weight of the administrative elites and their sciences of government in the landscape of legitimate producers of knowledge on these policies (Pons, 2017). In the case of Portugal, it seems difficult not to consider the political history of the school system and its visibly important effects on the structuring of research in sociology of education. The synthesis of the development of this sociology proposed by Leonor Lima Torres, Mariana Gaio Alves and Bruno Dionísio shows that each stage of the relationship between political reform, teaching and educational research has had an influence on the way educational policies have been studied. According to these authors, research on education policy has evolved from macrostructural approaches focused on the dynamics of the functioning of the education system (1970s) to the analysis of education policies specific to the democratic revolution (1980s), before moving from the 1990s towards a diversification of the scales of analysis, to focus in recent years on what the authors call the «mega-level», i.e. far-reaching education policies implemented in a context of globalisation. It is therefore possible that the trend identified above of a strong emphasis by researchers on the Europeanisation and globalisation of Portuguese educational policies is not only linked to a source effect, but also to a conjuncture effect (Lima Torres et al., 2017).

\section{Conclusion}

In conclusion, we would like to highlight three avenues that we believe could be fruitfully pursued to work towards the construction of a common problematisation space for thinking about the education policies implemented in the countries of southern Europe. The first would be to deepen the analysis of the processes of vernacularisation of education policies already studied by several authors of our corpus 
(Barzanò \& Grimaldi, 2013; Grimaldi \& Serpieri, 2013b; Maroy et al., 2017), in connection with the reflections of Arjun Appaduraï and their introduction into educational research by Bob Lingard. By insisting on the role of cultural contexts that are more or less generative of specific globalized practices (and policies), this approach may be a stimulating way to analyse not only the framing power of policy contexts specific to certain Southern European countries, but also the different logics of vernacularisation at work in each case. The second would be to mobilise more strongly the achievements of policy analysis, whether it is carried out from sociology or political science. Many works on education policies at the international level are devoted to discourse analysis without always paying sufficient attention to the actors, institutions, representations, instruments and even the very policy processes, all of which are elements that a well-contextualised policy analysis could better consider. The third would be to capitalise even more on a corpus of sociological references which are in fact already shared by several researchers (such as the sociology of translation, for example) but which are not always sufficiently discussed in common.

We hope that these avenues, but also the necessary overcoming of the limitations of our literature review mentioned above, will lead to cooperation between researchers who will further deepen the contextualisation logics of researchers working on education policies. We think that this perspective is central, not only for sociology, but also for improving the relationship between research and educational policies, a relationship that is often thought of according to an engineering model (Power \& Rees, 2020) that does not sufficiently consider the major role of social, cultural and political contexts.

\section{Bibliographical references}

Adrião, Theresa \& Silva, Rui da. (2020): "Public Funding to Private Providers of Compulsory Education: Crossed Looks Between Brazil and Portugal in the Context of Globalisations". Globalisation, Societies and Education, 18 (4), 420-434. DOI: https://doi.org/10.1080/14767724.2020.1764336.

Álvares, Maria (2018): "Fault Lines in Education: Dualization and Diversification of Pathways over 40 years of Debate on Education Policy in Portugal”. Sociologia, Problemas e Práticas, 87, 45-70.

Alves, Ines (2019): "International Inspiration and National aspirations: Inclusive Education in Portugal”. International Journal of Inclusive Education, 23 (7-8), 862-875. DOI: https://doi.org/10.1080/13603116. 2019.1624846.

Alves, Ines (2020): "Enacting Education Policy Reform in Portugal - the Process of Change and the Role of Teacher Education for Inclusion”. European Journal of Teacher Education, 43 (1), 64-82. DOI: https:/ / doi.org/10.1080/02619768.2019.1693995.

Antunes, Fátima (2004): “Globalização, europeização e especificidade educativa portuguesa: A estruturação global de uma inovação nacional”. Revista Crítica de Ciências Sociais, 70, 101-125. DOI: https:// doi.org/10.4000/rccs.1051.

Antunes, Fátima (2016): “Economising Education: From the Silent Revolution to Rethinking Education. A New Moment of Europeanisation of education?”. European Educational Research Journal, 15 (4), 410 427. DOI: https://doi.org/10.1177/1474904116641696. 
Arksey, Hilary \& O’Malley, Lisa (2005): “Scoping Studies: Towards a Methodological Framework.” International Journal of Social Research Methodology, 8 (1), 19-32. DOI: https://doi.org/10.1080/1364557032 000119616.

Ball, Stephen J. (1994). Education Reform: A Critical and Post-Structural Approach. Open University Press.

Ball, Stephen J. (2008): “New Philanthropy, New Networks and New Governance in Education”. Political Studies, 56 (4), 747-765. DOI: https://doi.org/10.1111/j.1467-9248.2008.00722.x.

Barlet, Sandra \& Jarousse, Jean-Pierre (2011): “Les ONG et l'éducation dans les pays en développement: Introduction”. Revue Internationale d'éducation de Sèvres, 58, 37-46. DOI: https:/ /doi.org/10.4000/ ries. 2153 .

Barrault-Stella, Lorenzo (2012): "Les résistances de la carte scolaire. Les limites du volontarisme politique dans l'action publique". Politix, 98 (2), 109-127. Cairn.info. DOI: https://doi.org/10.3917/ pox.098.0109.

Barrault-Stella, Lorenzo (2016): "Produire un retrait de l'État acceptable. Les politiques de fermetures scolaires dans les mondes ruraux contemporains". Gouvernement et action publique, VOL. 5 (3), 33-58. Cairn.info. DOI: https://doi.org/10.3917/gap.163.0033.

Barzanò, Giovanna \& Grimaldi, Emiliano (2013): “Discourses of Merit. The Hot Potato of Teacher Evaluation in Italy". Journal of Education Policy, 28 (6), 767-791. DOI: https://doi.org/10.1080/02680 939.2013.774439.

Berthet, Thierry (2019): "Dispersion scolaire et politiques publiques contre le décrochage en Italie". Formation Emploi, 147, 89-112. DOI: https://doi.org/10.4000/formationemploi.7643.

Bertiglia, Marina \& Panaro, Novarino (1996): “La politique scolaire rurale en Italie”. Revue Internationale d'éducation de Sèvres, 10, 75-82. DOI: https:// doi.org/10.4000/ries.3320.

Bongrand, Philippe (2012): “La mise en système et l'économicisation de l'enseignement en France au début des années 1950: La fonctionnalisation d'une institution”. Politix, 98 (2), 35-56. Cairn.info. DOI: https://doi.org/10.3917/pox.098.0035.

Borghi, Lamberto \& Scarangello, Anthony (1960): “Italy's Ten-Year Education Plan”. Comparative Education Review, 4 (1), 26-30. JSTOR.

Bowe, Richard; Ball, Stephen J., \& Gold, Anne (1992). Reforming Education and Changing Schools: Case Studies in Policy Sociology. London: Routledge.

Buisson-Fenet, H. (2004a). “Territoire flou, territoire approprié. Le cas des 'bassins de formation' dans l'Éducation nationale”. Lien social et Politiques, 52, 27-34. Érudit. DOI: https://doi. org/10.7202/010586ar.

Buisson-Fenet, Hélène (2004b): “Un 'usager' insaisissable? Réflexion sur une modernisation mal ajustée du service public d'éducation”. Éducation et sociétés, 14 (2), 155-166. Cairn.info. DOI: https://doi. org/10.3917/es.014.0155. 
Buisson-Fenet, Hélène (2007): "L'éducation scolaire au prisme de la science politique: Vers une sociologie politique comparée de l'action publique éducative ?’. Revue internationale de politique comparée, 14 (3), $385-$ 397. Cairn.info. DOI: https://doi.org/10.3917/ripc.143.0385.

Buisson-Fenet, Hélène \& Pons, Xavier (2012): “L’européanisation de l'École française en débat: Le cas contrasté de l'évaluation des établissements scolaires". Politix, 98 (2), 129-146. Cairn.info. DOI: https://doi.org/10.3917/pox.098.0129.

Carney, Stephen (2012): "Imagining Globalisation: Educational Policyscapes" in Gita Steiner-Khamsi and Florian Waldow (eds.): Policy Borrowing and Lending in Education. London: Routledge.

Carvalho, Luís Miguel \& Costa, Estela (2015): “Seeing Education with One’s Own Eyes and Through PISA Lenses: Considerations of the Reception of PISA in European Countries". Discourse: Studies in the Cultural Politics of Education, 36 (5), 638-646. DOI: https:// doi.org/10.1080/01596306.2013.871449.

Carvalho, Luís Miguel; Costa, Estela \& Sant'Ovaia, Carlos (2020): "Depicting the Faces of Results-Oriented Regulatory Processes in Portugal: National Testing in Policy Texts". European Educational Research Journal, 19 (2), 125-141. DOI: https://doi.org/10.1177/1474904119858799.

Charlier, Jean-Emile (2003): “L'influence des organisations internationales sur les politiques d'éducation". Éducation et Sociétés, 12, 5-11.

Clément, Pierre (2021): “The Introduction of Competence-Based Education into the Compulsory School Curriculum in France (2002-2017): Hybridity and Polysemy as Conditions for Change". Comparative Education, 57 (1), 35-50. DOI: https://doi.org/10.1080/03050068.2020.1845062.

Connell, Raewyn (2007). Southern Theory. Cambridge: Polity Press.

Coombs, F. S. (1978): “The Politics of Educational Change in France". Comparative Education Review, $22(3), 480-503$. JSTOR.

De Renzo, Francesco (1997): “Un Projet de Rénovation Générale: Le Système Éducatif Italien”. Revue Internationale d'éducation de Sèrres, 15, 83-97. DOI: https://doi.org/10.4000/ries.3173.

Derouet, Jean-Louis (2006): "Entre la récupération des savoirs critiques et la construction des standards du management libéral: Recherche, administration et politique en France de 1975 à 2005”. Revue des sciences de l'éducation, 32 (1), 7-30. Érudit. DOI: https://doi.org/10.7202/013474ar.

Derouet, Jean-Louis. (2008): “Interroger les nouvelles politiques d'éducation et de formation en France depuis 25 ans: Une recomposition parallèle des conceptions de la justice et des formes de l'État". Sociologie et sociétés, 40 (1), 57-68. Érudit. DOI: https://doi.org/10.7202/019472ar.

Dobbins, Michael \& Martens, Kerstin (2012): "Towards an Education Approach à la Finlandaise? French Education Policy after PISA”. Journal of Education Policy, 27 (1), 23-43. DOI: https://doi.org/10.1080 /02680939.2011.622413.

Dupuy, Claire (2012): “Ce que la comparaison qualitative de politiques infranationales fait aux débats théoriques". Revue internationale de politique comparée, 19(2), 121-139. Cairn.info. DOI: https://doi. org/10.3917/ripc.192.0121. 
Dupuy, Claire \& Pollard, Julie (2013): “Les limites du pouvoir de l’État dans les territoires. Les politiques de l'État dans le secteur de l'éducation et du logement en France". Sciences de La Société, 90, 22-41. DOI: https://doi.org/10.4000/sds.493.

Dutercq, Yves (2009): "L'influence des collectivités territoriales sur la politique d'éducation en France" en Guy Pelletier (ed.): La gouvernance en éducation: Régulation et encadrement dans les politiques éducatives. Bruxelles: De Boeck Supérieur.

Engel, Laura C. \& Rutkowski, David (2014): “Global Influences on National Definitions of Quality Education: Examples from Spain and Italy". Policy Futures in Education, 12 (6), 769-783. DOI: https:/ doi. org/10.2304/pfie.2014.12.6.769.

Estrela, Elsa (2019): “The Knowledge of Policies: The Personal Dimension in Curriculum Policies in Portugal”. British Journal of Educational Studies, 67 (2), 217-233. DOI: https://doi.org/10.1080/000710 05.2018.1444730.

Ferreira, Fernando Ilídio (2007): “Transformation de l'école et paradoxes de l'autonomie au Portugal”. Revue Internationale d'éducation de Sèvres, 46, 45-54. DOI: https://doi.org/10.4000/ries.593.

Feuerhahn, Wolf (2017): “Les sciences humaines et sociales: Des disciplines du contexte ?”. Revue d'histoire Des Sciences Humaines, 30, 7-29. DOI: https://doi.org/10.4000/rhsh.493.

Garcia, Nuria (2015): “Tensions Between Cultural and Utilitarian Dimensions of Language: A Comparative Analysis of 'Multilingual' Education Policies in France and Germany”. Current Issues in Language Planning, 16 (1-2), 43-59. DOI: https://doi.org/10.1080/14664208.2014.947015.

García Redondo, Eva (2016): “La gobernanza en las Instituciones de enseñanza en Portugal”. Journal of New Approaches in Educational Research, 6(1), 17-22. DOI: https://doi.org/10.7821/ naer.2016.1.156.

Gauthier, Roger-François \& Le Gouvello, Margaux (2010): “The French Curricular Exception and the Troubles of Education and Internationalisation: Will it be Enough to 'Rearrange the Deckchairs'?". European Journal of Education, Part I., 45(1), 74-88. DOI: https://doi.org/10.1111/j.14653435.2009.01416.x.

Grek, Sotiria (2009): "Governing by Numbers: the PISA Effect in Europe". Journal of Education Policy, $24(1), 23-37$.

Grimaldi, Emiliano (2012a): "Analysing Policy in the Context(s) of Practice: A Theoretical Puzzle". Journal of Education Policy, 27 (4), 445-465. DOI: https://doi.org/10.1080/02680939.2011.647926.

Grimaldi, Emiliano (2012b): "Neoliberalism and the Marginalisation of Social Justice: The Making of an Education Policy to Combat Social Exclusion”. International Journal of Inclusive Education, 16 (11), 1131 1154. DOI: https://doi.org/10.1080/13603116.2010.548105.

Grimaldi, Emiliano (2013): "Old and New Markets in Education: Austerity, Standards and ICT as Pushes towards Privatisation(s) in Italy". European Educational Research Journal, 12 (4), 425-446. DOI: https:/ / doi.org/10.2304/eerj.2013.12.4.425. 
Grimaldi, Emiliano \& Barzanò, Giovanna (2014): "Making Sense of the Educational Present: Problematising the 'merit Turn' in the Italian Eduscape". European Educational Research Journal, 13 (1), 26-46. DOI: https://doi.org/10.2304/eerj.2014.13.1.26.

Grimaldi, Emiliano \& Landri, Paolo (2019): “Tackling Early School Leaving and the Governing of Educational Transitions in Italy”. Comparative Education, 55 (3), 386-403. DOI: https://doi.org/10.1080/ 03050068.2019.1619332.

Grimaldi, Emiliano \& Serpieri, Roberto (2013a): "Privatising Education Policy-Making in Italy: New Governance and the Reculturing of a Welfarist Education State". Education Inquiry, 4 (3), 22615. DOI: https://doi.org/10.3402/edui.v4i3.22615.

Grimaldi, Emiliano \& Serpieri, Roberto (2013b): "Jigsawing Education Evaluation. Pieces from the Italian New Public Management Puzzle". Journal of Educational Administration and History, 45 (4), 306-335. DOI: https://doi.org/10.1080/00220620.2013.822350.

Grimaldi, Emiliano \& Serpieri, Roberto (2013c): "Italian Education Beyond Hierarchy: Governance, Evaluation and Headship". Educational Management Administration \& Leadership, 42 (4_suppl), 119-138. DOI: https://doi.org/10.1177/1741143213510501.

Gunter, Helen; Grimaldi, Emiliano; Hall, David \& Serpieri, Roberto (2016). New Public Management and the Reform of Education: European Lessons for Policy and Practice. London: Routledge. http:/ / site.ebrary.com/ id/11235033.

Hall, David; Grimaldi, Emiliano; Gunter, Helen; Møller, Jorunn; Serpieri, Roberto \& Skedsmo, Guri (2015): "Educational Reform and Modernisation in Europe: The Role of National Contexts in Mediating the New Public Management". European Educational Research Journal, 14(6), 487-507. DOI: https://doi.org/10.1177/1474904115615357.

Halpern, Charlotte; Hassenteufel, Patrick \& Zittoun, Philippe (2018). Policy Analysis in France. Bristol: Policy Press.

Hardy, Ian; Heikkinen, Hannu \& Olin, Anette (2020): “Conceptualising and Contesting 'Fast Policy' in Teacher Learning: A Comparative Analysis of Sweden, Finland and Australia”. Teacher Development, 24 (4), 466-482. DOI: https://doi.org/10.1080/13664530.2020.1776761.

Heurdier, Lydie (2014): "La politique d'éducation prioritaire. Un projet conduit hors du champ politique (1981-2001)". Vingtième Siècle. Revue d’histoire, 124 (4), 155-168. Cairn.info. DOI: https://doi. org/10.3917/vin.124.0155.

Heurdier, Lydie (2016): “Expansion et transformation de l'enseignement spécial: Le tournant des années 1960". Carrefours de l'éducation, 41 (1), 133-149. Cairn.info. DOI: https://doi.org/10.3917/ cdle.041.0133.

Hyatt, David \& Meraud, Julie (2015): “Teacher Education in France Under the Hollande Government: Reconstructing and Reinforcing the Republic". Journal of Education for Teaching, 41 (3), 218-234. DOI: https://doi.org/10.1080/02607476.2015.1044227. 
Jakobi, Anja P. (2009): "Global Education Policy in the Making: International Organisations and Lifelong Learning”. Globalisation, Societies and Education, 7 (4), 473-487. DOI: https://doi. org/10.1080/14767720903412275.

Jakobi, Anja P. (2012): "International Organisations and Policy Diffusion: The Global Norm of Lifelong Learning". Journal of International Relations and Development, 15 (1), 31-64. DOI: http://dx.doi. org/10.1057/jird.2010.20.

Lahire, B. (1996): “La variation des contextes en sciences sociales: Remarques épistémologiques”. Annales. Histoire, Sciences Sociales, 51 (2), 381-407.

Landri, Paolo (2015): "The Sociomateriality of Education Policy". Discourse: Studies in the Cultural Politics of Education, 36 (4), 596-609. DOI: https://doi.org/10.1080/01596306.2014.977019.

Lawn, Martin (2006): "Soft Governance and the Learning Spaces of Europe". Comparative European Politics, 4(2-3), 272-288. DOI: https://doi.org/10.1057/palgrave.cep.6110081.

Lawn, Martin \& Grek, Sotiria (2012). Europeanizing Education: Governing a New Policy Space. Oxford: Symposium Books. https://books.google.fr/books?id=IixwCQAAQBAJ.

Lima Torres, Leonor; Gaio Alves, Mariana \& Dionísio, Bruno (2017): “Enseigner, chercher, intervenir : explorer les horizons possibles de la sociologie de l'éducation au Portugal". Éducation et sociétés, 40, 185202. DOI: https://doi.org/10.3917/es.040.0185

Lingard, Bob; Martino, Wayne \& Rezai-Rashti, Goli (2013): “Testing Regimes, Accountabilities and Education Policy: Commensurate Global and National Developments". Journal of Education Policy, 28 (5), 539-556. DOI: https://doi.org/10.1080/02680939.2013.820042.

Lingard, Bob \& Rawolle, Shaun (2011): "New Scalar Politics: Implications for Education Policy”. Comparative Education, 47 (4), 489-502. DOI: https:/ / doi.org/10.1080/03050068.2011.555941.

Lingard, Bob \& Sellar, Sam (2013): “Globalization, Edu-business and Network Governance: The Policy Sociology of Stephen J. Ball and Rethinking Education Policy Analysis". London Review of Education. DOI: https://doi.org/10.1080/14748460.2013.840986.

Lingard, Bob \& Sellar, Sam (2014): "The OECD and the Expansion of PISA: New Global Modes of Governance in Education". British Educational Research Journal, 40 (6), 917-936. DOI: https://doi. $\operatorname{org} / 10.1002 /$ berj. 3120 .

Maroy, Christian (2009): "Convergences and Hybridization of Educational Policies Around 'Post-Bureaucratic' Models of Regulation”. Compare: A Journal of Comparative and International Education, 39 (1), 71-84. DOI: https://doi.org/10.1080/03057920801903472.

Maroy, Christian (2013). L'école à l'épreuve de la performance: Les politiques de régulation par les résultats. Bruxelles: De Boeck.

Maroy, Christian; Pons, Xavier \& Dupuy, Claire (2017): "Vernacular Globalisations: Neo-Statist Accountability Policies in France and Quebec Education". Journal of Education Policy, 32(1), 100-122. DOI: https://doi.org/10.1080/02680939.2016.1239841. 
Maroy, Christian; Pons, Xavier (forthcoming): "Globalization, New Institutionalisms and the Political Dimension" in Paola Mattei, Xavier Dumay, Eric Mangez and Jacqueline Behrend (eds.): Oxford Handbook on Education and Globalization. Oxford University Press, forthcoming.

Marques Cardoso, Clementina (2008): “Government-Microsoft Partnerships: Supranational Formulation in Private and Public Policy". Globalisation, Societies and Education, 6 (3), 241-264. DOI: https:// doi. org/10.1080/14767720802343324.

Mathou, Cécile (2018): "Recontextualizing Curriculum Policies: A Comparative Perspective on the Work of Mid-Level Actors in France and Quebec". Journal of Curriculum Studies, 50 (6), 789-804. DOI: https://doi.org/10.1080/00220272.2018.1513567.

Mays, Nicholas; Roberts, Emilie \& Popay, Jennie (2001): "Synthesising Research Evidence" in Naomi Fulop, Pauline Allen, Aileen Clarke, \& Nick Black (eds.): Studying the Organisation and Delivery of Health Services: Research Methods. London: Routledge.

Mesquita, Leopoldo (2012): "The Entrepreneurialisation of School Work as a Central Theme in Present Educational Changes: The Portuguese Case". Journal of Educational Administration and History, 44 (2), 141-153. DOI: https://doi.org/10.1080/00220620.2012.658762.

Michel, Alain (2017): "The Contribution of PISA to the Convergence of Education Policies in Europe: MICHEL”. European Journal of Education, 52 (2), 206-216. DOI: https://doi.org/10.1111/ejed.12218.

Mons, Nathalie (2007). Les nouvelles politiques éducatives: La France fait-elle les bons choix? Paris: PUF.

Müller, Jörg \& Hernández, Fernando (2010): “On the Geography of Accountability: Comparative Analysis of Teachers' Experiences Across Seven European Countries”. Journal of Educational Change, 11 (4), 307-322. DOI: https://doi.org/10.1007/s10833-009-9126-x.

Normand, Romuald (2010): "Expertise, Networks and Indicators: The Construction of the European Strategy in Education". European Educational Research Journal, 9(3), 407-421. DOI: https://doi. org/10.2304/eerj.2010.9.3.407.

Normand, Romuald; Liu, Min; Carvalho, Luís Miguel; Oliveira, Dalila Andrade \& Levasseur, Louis (2019). Education Policies and the Restructuring of the Educational Profession: Global and Comparative Perspectives. Singapore: Springer.

Nóvoa, António \& Lawn, Martin (eds.). (2002). Fabricating Europe: The Formation of an Education Space. Dordrecht: Springer. DOI: https://doi.org/10.1007/0-306-47561-8.

Olivier de Sardan, Jean-Pierre (2021). La revanche des contextes: Des mésaventures de l'ingéniérie sociale, en Afrique et au-delà. Paris: Karthala.

Ozga, Jenny (2011). Fabricating Quality in Education: Data and Governance in Europe. London: Routledge.

Passeron, Jean-Claude (2006). Le raisonnement sociologique: Un espace non poppérien de l'argumentation. Paris: Albin Michel.

Passeron, Jean-Claude \& Revel, J. (2005). Penserpar cas. Paris: École des hautes études en sciences sociales. 
Peck, Jamie \& Theodore, Nik (2010): "Recombinant Workfare, Across the Americas: Transnationalizing "Fast" Social Policy". Geoforum, 41(2), 195-208. DOI: https://doi.org/10.1016/j.geoforum.2010.01.001.

Pons, Xavier (2012a): “Going Beyond the 'PISA Shock' Discourse: An Analysis of the Cognitive Reception of PISA in Six European Countries, 2001-2008”. European Educational Research Journal, 11 (2), 206-226. DOI: https://doi.org/10.2304/eerj.2012.11.2.206.

Pons, Xavier (2012b): "De nouvelles connaissances pour une nouvelle gouvernance par les résultats? L'exemple de l'éducation en France et de trois outils d'évaluation". Recherches Sociologiques et Anthropologiques, 43 (2), 15-34. DOI: https://doi.org/10.4000/rsa.784.

Pons, Xavier (2017): "Réforme administrative et recherche dans les revues d'interface: L'exemple de l'accountability en éducation en France". Revue française de pédagogie, 201 (4), 41-51. Cairn.info. DOI: https://doi.org/10.4000/rfp.7206.

Power, Sally \& Frandji, Daniel (2010): "Education Markets, the New Politics of Recognition and the Increasing Fatalism Towards Inequality". Journal of Education Policy, 25 (3), 385-396. DOI: https:// doi. org/10.1080/02680930903576404.

Power, Sally \& Rees, Gareth (2020): "Conceptualising the Sociology of Education: An Analysis of Contested Intellectual Trajectories”. British Journal of Sociology of Education, 41 (6), 778-793. DOI: https:/ / doi.org/10.1080/01425692.2020.1784708.

Robert, Bénédicte (2007): "Les politiques scolaires de compensation en France et aux États-Unis. Diversité des acceptions et convergence des choix". Revue internationale de politique comparée, 14 (3), 437-448. Cairn.info. DOI: https://doi.org/10.3917/ripc.143.0437.

Rochex, Jean-Yves (2008): "Vingt-cinq ans de politique d'éducation prioritaire en France: Une spécificité incertaine et des résultats décevants". Les Politiques d'éducation Prioritaire En Europe. Conceptions, Mises En Oeuvre, Débats, 135-174.

Rochex, Jean-Yves (2016): "Faut-il crier haro sur l'éducation prioritaire ? Analyses et controverses sur une politique incertaine”. Revue Française de Pédagogie, 194, 91-108. DOI: https://doi.org/10.4000/rfp.4981.

Rochex, Jean-Yves (2018): "L'éducation prioritaire en France: Les paradoxes d'une politique incertaine". Administration \& Éducation, 159 (3), 101-103. Cairn.info. DOI: https://doi.org/10.3917/admed.159.0101.

Romito, Marco (2019): “Governing through Guidance: An Analysis of Educational Guidance Practices in an Italian Lower Secondary School”. Discourse: Studies in the Cultural Politics of Education, 40 (6), 773 788. DOI: https://doi.org/10.1080/01596306.2017.1314251.

Santagati, Mariagrazia; Bertozzi, Rita; Beltrán Llavador, José \& Villar-Aguilés, Alícia (2019): “At the Margins: Challenges for Sociologists of Education in Southern Europe". Revista de Sociología de La Educación-RASE, 12 (3), 361. DOI: https://doi.org/10.7203/RASE.12.3.15862.

Santos, Boaventura de Sousa (2014). Epistemologies of the South. London: Routledge. 
Santos, Íris (2021): "Epistemic Work in Portuguese Parliamentary Education Debates: Externalisation to World Situations as a Source of Epistemic Capital”. European Educational Research Journal, February 2021. DOI: https://doi.org/10.1177/1474904121990474.

Serpieri, Roberto; Grimaldi, Emiliano \& Vatrella, Sandra (2015): "School Evaluation and Consultancy in Italy. Sliding Doors Towards Privatisation?". Journal of Educational Administration and History, 47 (3), 294-314. DOI: https://doi.org/10.1080/00220620.2015.1038695.

Teodoro, António \& Estrela, Elsa (2010): “Curriculum Policy in Portugal (1995-2007): Global Agendas and Regional and National Reconfigurations”. Journal of Curriculum Studies, 42 (5), 621-647. DOI: https://doi.org/10.1080/00220271003735728.

Topalov, Christian (ed.). (1999). Laboratoires du nouveau siècle: La nébuleuse réformatrice et ses réseaux en France, 1880-1914. Paris : Ecole des hautes études en sciences sociales.

\section{Biographical note}

Xavier Pons es is Professor in Education at the University of Paris Est Créteil (UPEC), researcher at the Interdisciplinary Research Laboratory on Transformations of Educational and Social Practices (Lirtes, EA 7313) and associate researcher at the Center for social change (OSC-Sciences Po, UMR 7049). A member of several comparative research projects, his work on the sociology of policies and public problems focuses mainly on transformations of the state and modes of governance in education, reforms of school administrations, the mediatisation of educational problems and the ways in which public debate in education is structured. Winner of the 2011 Jean-Claude Eicher Prize for the Development of Educational Research, he is also co-editor of the Revue française de pédagogie.

ORCID: https://orcid.org/0000-0002-4431-9844. 